\title{
Functions of Nachhung (Shaman) in the Chamling Rai in Eastern Nepal
}

Rai Puspa Raj

\begin{abstract}
Rai is an indigenous people and decedent of Kirati dynasty, inhabitant of eastern part of Nepal. It is known as Kirat Pradesh before the unification of Nepal. Now, Kirat Pradesh is became political word in Nepal for name of province number 1 but not endorse till present. The Chamling Rai society is comprised different interdependent parts and units as like religion, culture, economy, polity, educational etc. Kirat religion is a part of Rai community constituted by the different units and interdepended among different parts. The Chamling word Nachhung (shaman) is called priest of the Kirat religion. So, this article focuses on the Nachhung who is the Rai priest, shaman and healer as functional unit of the Rai society. The main research questions if how the Nachhung plays function as the being part of Rai society and contribute to existence of Rai society as whole. It explores the interdependence of Nachhung on other parts like rite and ritual, marriage, feast and festival, community, health, social and religious activities.
\end{abstract}

Keywords: Nachhung's function, rite and ritual, Sakela festival, healing illness.

\section{Introduction}

Shamanism is a kind of religion in the primitive society. Tylor argues that animism is the first religion of the world. There was found debate on shamanism among different scholars in 19th centuray. Tylor, Schmidt considered shamanism as primitive religion but Durkhiem, Marcel Mauss considered magic as immoral and private act. Malinowski, Radcliffe-Brown and Evan Pritchard considered magic as religion, which function is social control and maintenance social value. Later, Marett and Hultkranz saw magic is a part of religion and shamanism is a genuine religion (Walter, 2004).

'Shaman is an inspired prophet and healer, a charismatic religious figure, with the power to control the spirits, usually by incarnating them. If spirits speak through him, he is also likely to have the capacity to engage in mystical flight and other out-of body experiences' (Lewis, 1984:9). 'A shaman is one who has direct communication with spirits, is in control of spirits and altered states of consciousness undertakes some magical flights to the spirit world' (Townsend, 1997:1). 
Religion is the social glue of the society which maintains social solidarity. It is a highly collective thing. The totemic objects kept for religious rituals which are the representation of the clan or tribe, community (Haralambas \& Heald, 2003).

Nepali society is diverse in terms of culture, religion, language etc. So, it is fertile land for shamanistic study. Foreign scholars such as McDonald, Sagant, Jones, Hitchcock, Reinhard, Allen have carried out research on Nepali Shamanism in the decade of 1970s. Later, many scholars have done research on Nepali shaman. In this context, this article is concentrated on the functions of Nachhung (Shaman) of Chamling Rai in Khotang district.

\section{Statement of the Problem}

Shamanistic research was started by foreigner during the decade of 1970s in Nepal. Sagant (1976), Jones (1976), Hitchcock (1976) and MacDonald (1979) carried out research of shamanism of Nepal in different caste and ethnic groups. Jones and Sagant studied of Limbu shaman. MacDonald studied Kulung Rai. All These scholars focus on origin of shaman by mythical process. Allen (1976) studied Thulung Rai Shaman. Reinhard (1976) studied Raji community, shaman find out cause of disease by feeling of the pulse and reading rice grains.

Bista (1996) describes the role of Nakcho (shaman) as religious leader, including to only death ritual of Rai. Gaenszle (2004) describes the shaman and priest as ritual specialists. Hatuwali (B.S. 2064) describes the Nachhung role in Sakela festivals.

Schlemmer (2019) classifies types of shaman and role of shaman in death ritual in Kulung Rai community. Kirat Rai Chamling Khambatimma, (B.S. 2071) classifies the Rai shaman as Home or Khatwa performs natural death rites. Other shaman like Mapa or Mopa performs the unnatural death rites but gives more attention on collection of Mundum.

Various studies after 1990 are concentrated on ethnic discrimination and ethnic politics in Nepal. A few of studies are centralized on the shamanism of Rai, but less research has done on Nachhung's function in Chamling Rai.

So this paper's main research question is how the Nachhung is originated in Chamling Rai? Second research question is how the Nachhung plays function as the being part of Chamling Rai society and contribute to existence of Chamling Rai society as whole?

\section{Research Methods}

Diprung Chuichumma Rural Municipality ward no. 2 \& 3 (Dandaguan and Batase), Khotang district has been selected as the study area. The rational for selection of this study area is Majah Kirat and densely populated of Rai. The universe of the study is unknown, but the sampling unit is Rai shaman, Rai cultural expert who is called Hosung and Pasung 
(elderly person). Primary and secondary data have been collected by the open ended interview schedule. Key informant Interview schedule has been used to get detail information about to identify the function of Nachhung. Researcher reached in the field site then planned for interview and some informal dialogue were conducted with member of Waitung (Social Organization). Qualitative data has been interpreted. Through data screening, coding, editing then interpretation has been done. It is limited only Chamling Rai area and does not cover other areas of Rai.

\section{Brief Introduction to Rai}

Rai is an indigenous ethnic group and descendent of Kirati dynasty, ruled over thirty-three descent of Nepal. 'Kirat Pradesh' is the ancestral land of the Rai people. Kirat Pradesh is situated in eastern part of modern Nepal, which is divided into Wallo Kirat (near Kirat), Majha Kirat (middle Kirat) and Pallo Kirat (far Kirat). Majha Kirat covers Solukhumbu, Okhaldhunga, Khotang and Bhojpur.

Historically, there is no exact date of the when did Kirati become Rai but the term 'Rai' term originated from 'Ray', which means 'the king'. Many researchers have concluded that when Prthivinarayan Shah captured middle Kirat and far Kirat then he appointed local Kirati to work as intermediaries' local people. Then, Khumbu concluded was given the title 'Rai', means 'chief' or 'headman' (Bista, 1996). These headmen were given royal commissions and the honorific title 'Rai' (McDougal, 1979). Nowadays, almost of the Kirati indigenous people use 'Rai' title as their last name that identifies them from generation to generation. Now, it becomes the surname of all Rai people. The Rai is a division of the Kirati people. Rai tribe can be defined as the segmental divisions who have common cultural trait and similar cultural element. Rai is not a single tribe but comprises different subtribe. Rai has been divided into 35 sub-tribes, which are Athpahriya, Thulung, Bantawa, Wambule, Khaling, Nachhiring, Chamling etc. Each sub-tribes have distinct cultural and social structure. "Das Rai, Das Bhasa, eka Bhansa" (Ten Rais, Ten languages, one Kitchen) proverb shows that unity in diversity of Rai community. Chamling is one of the subtribe of Rai.

\section{Origin of Nachhung (Shaman)}

According to Tylor, animism is the earliest form of religion which means the belief system in spirits (Harlambas \& Heald, 1980). Rai are animistic, who worship nature like river, mountain, rock, tree, stream. They believe that all natural things have soul.

Lewis defines that 'shaman is an inspired prophet, healer, and a charismatic religious figure with the power to control the spirits, usually by incarnating them. If spirits speak through 
him, he is also likely to have the capacity to engage in mystical flight and other out-of-body experiences' (Lewis, 1984:9)

According Mundum, Mubumi (cuckoo bird) was first shaman and Kubumi (Kuthurke bird) was first assistance of shaman (Kirat Rai Chamling Khambatima, B.S. 2071). Laladum and Dolemku (female forest spirit) make shaman in Kulung Rai community. Those persons who are selected by Laladum and Dolemku became shaman. They give the power to see the invisible and to divine future (Schlemmer, 2019).

Nachhung is the main priest of Rai and who performs the all kind of cultural activities. Nachhung also plays role as mediator to worship natural things and ancestors. Their ancestors' soul is immortal so Rai people used to Nachhung for resting their ancestor soul in Chula as household deity. Nachhung worships ancestor soul on the occasion of Udhauli (downward) and Ubhauli (upward) twice in year.

According to Key informant Jukta Bahadur Rai, understanding the origin of Nachhung needs to take help from Mandum. Mundum is the orally recited text by Nachhung, which is also called Thuturi (orally) Veda of Rai. Nachhungs are the main source of Mundum, who preserve the Mundum their memory and transfer to other Nachhung. He elaborates as follow:

Paruhang (god of sky) offered marriage proposal to Nayima (god of earth). Nayima rejected the marriage proposal of Paruhang due to unattractive physical appearance of Paruhang. Powerful god Paruhang thought take revenge of Nayima behavior toward him. Paruhang is supreme powerful god who can create, destroy, and protect all creatures of universe. He broke the wing of wind, then drought was started, all river, stream, pond were dry. Nayima having strong desire for drinking water but she could not found drinking water. Chibe Bird (bronzed drong) helped to bring drinking water. Bronzed drong gave Karkalo leaf water. Nayima drank Karkalo leaf water for satisfying her thirsty. It was not water but it was semen of Paruhang. Nayima was conceives sperm of Paruhang. Gradually, Nayima physical appearance was change and felt uneasy and illness. In this situation, she was called different types of shaman such as Kul Dhami, Khatwa Dhami. Khatwa Dhami found out the cause of illness of Nayima, she was pregnant.'

-Interview with Jukta Bahadur Rai, 2076/03/18

From this statement, Nachhung origination main source is Paruhang. Paruhang created the universe, species and animals. God created the Nachhung to care of all creatures in the earth, Nachhung is as a mediator between god and creatures. Individual or personal interest and wants is not suit for origin of Nachhung. Nachhung is selected by Paruhang and Nayiama. Some Nachhung are selected by the spirits, which has lower power. 
According to Nachhung Hast Bahadur Rai, Nachhung was created by Paruhang, person who will be selected as Nachhung has different signs, do different activities and has different dreams with god, and goddess. The main symptom is body while listening sound of playing drum, cymbal and brass plate. Another symptom is ill feeling when eat mutton, and take meal in funeral rite. Nachhung Akash Rai also argues that the origination of Nachhung by abduction of Banjahnkri (god of forest). There were so many Nachhungs were found in the period of Nayima illness. These Nachhung were Kalchuada Dhami, Mul Dhami. Gardi Machha Dhami, Kahula Dhami, Katahar Dhami.

The type of Nachhung is based on the origination and functions. Generally, both male and female can be originated as Nachhung (shaman), there is no clear gender division on Nachhung, little division on seen like Nachhung is male shaman and Nachhungma is female shaman. Nachhung classification is based on three criteria, which are: a. based on evolution: Mapa, Mubi, Surlumi b) based on cultural function: Mapa, Khatwa, Ruchipa and c) based on Mundumi Nachhung path: Khatwa and Mapa (Kirat Rai Chamling Khambatimma, B.S. 2071). But the main divisions of Nachhung are Khatwa, Mapa and Sakela Nachhung. Similarly, two types of Shaman namely Mopa and Selewa are found in the Kulung Rai. Female shaman is called Mopped (Nicoletti, 2004).

Nachhung are widely accepted by all clan members and their Waitung (social organization) meeting.The types of Nachhung is called in Nepali word Pagari Dhami (recognized shaman). It is also called Kul Dhami (priest shaman). After the selection, he/she function as the Rai priest in the society who gets Dhami pathi (food grain for Shaman). Rai people believe that Nachhung is the living intellectual property, whose role is guideline and protect the Rai society by mediating the god and goddess.

\section{Nachhung's Function in House construction, Establishment of household deities (Mochhama and Chula)}

Rai are naturalism, so respect to earth as god. Rai people believe that there should be worship the earth before new house construction. Nachong purifies weapons, which used in making house and sacrifice cock.It's symbolic meaning is to get protection from any accident from the house making (Mukarung, B.S. 2065).

Nachhung Parkash Rai elaborated the function of Nachhung in Rai house construction and establishment of Chula as household deity. Rai people worship earth as a Mother Nature and Sky as father nature. They always pay homage to Bokhama (earth) and Haikham (sky). 
Before the starting of house construction, Rai people invite to Nachhung for checking the soil, where they are going to make house. Nachhung's function is to examine soil based on divine power getting by Paruhang and Sumnima. Nachhung declares that soil is good or bad for house construction. After the selection of the best place, Nachhung worships the Bokhama (earth) with recitation of Mundum. Then, the function of Nachhung is to purify the weapons that are worshiped by Nachhung spreading local beer, blood of sacrificed cock.

The Chula is simply three stones but its cultural importance is very high. It is sacred thing of all Rai house. Its importance is very high in every aspect of Rai people. All rituals depend on the worshiping of Chula (Hullung in Chamling Rai language) Puja for example Ubhauli (going up), Udhauli (going down), marriage ritual, death ritual start from the Chula (Mukarung, B. S. 2065). Rai (B.S. 2075) presents the importance of Chula in Bantawa Rai. It is Hutlung in Bantawa Rai language. Hutlung is belief of supernatural power and sacred things. It is the basic foundation of all rituals of Bantawa Rai (Rai B.S. 2075). Sakhewa Nachhung should worships at Chula for taking power from the Chula, otherwise do not well perform in Sakhewa worship (Rai, 2073).

Mukarung (2065) categorized that the Chula three stone pillars like Diwalung, Tayalung and Ruthulung, that means ancestors, universe and nature (Mukarung, B.S. 2065).

Key informant informed that Chula is made by three erected stones, which are symbolized by ancestors' soul, and household deity. The names of three stones are Pakhlung, Makhalung, Siptilung. Pakhulung is placed in the right side, which represents the ancestors, Makhalung is erected in the left side, which represents the relative of mother and Siptulung is the main household deity. Fire is symbol of the power and light that burn all types of evils and bad and gives light to choose right path.

The function of Nachhung is changing physical house into cultural house. Nachhung is invited in new house for resting three stones as sacred Chula. In this rite, relative, near neighbors are invited in the new house. Nachhung consecrates the three stones pillar as sacred. All presence participants make collective consciousness, these stones as their god and goddess. Maundhum hymns are recited and cock is sacrificed, offering food grain, and local beer. Rai people worship Chula Udhauli and Ubhauli in a year, when Nachhung takes crucial role for worshiping Chula during Udhauli and Ubahuali in the Rai community.

Mochhama is the household deity of Rai, who protects the household from evils. It is positioned on the separate room which is called Dechhem. Mochhama establishment rite requires Nachhung compulsorily. Nachhung main role is resting the household deity in new house. All clan members participate, it is valuable new household owner. He/she gets the 
cultural identity and cultural name of house. Nachhung purifies the Mochhama to continue clan we-feelings and integrations.

\section{Nachhung's function in Chhauwa or Chhirinam Festival}

According to the key informants, it is newly harvested crops offering festival. Rai do not eat newly harvested corps especially ginger after performing Chhauwa or Chhirinam (Udhauli/downward of sun). In this occasion, Rai people worship their household deities like Chula Puja (sacred oven, where three stones are symbolized) and Mochhama Puja by offering new cultivated goods like ginger, paddy, maize, millet etc. Nachhung (Rai priest) performs Chula Puja by sacrificing cock, ginger, Jaand (local made fermented millet by used yeast). In this festival, Nachhung was compulsory need to worship god and goddess. Now, Nachhung is not compulsory need to worship due to changing role of Nachhung. Its function is replaced by the elder people who know about the Mundhum (religious text of Rai). Nachhung Hast Bahadur gives priority on the past history of role of the Nachhung in Chhauwa festival. Chula Puja is not easy, it is so difficult to do Chula Puja in accordance with Mundum. Nachhung who has knowledge and power by given Paruhang and Sumnima can worship Chula Puja and performing Chauwa festival. Nowadays, the decreased function of Nachhung in Chauwa is imperfect of Chhauwa festival of Rai.

\section{Nachhung's function in Sakela or Ubhauli Festival}

Sakela is a great festival of Rai, which is celebrated during Baishakhe Purnima (full moon day in the Baishakha), and Mangsire Purnima (full moon day in the Mangsir). Baishakhe Purnima is also called Ubhauli (upward) festival, is associated with good farming and plantation. Similarly, Mangsire Purnima is also called Udhauli (downward) is associated with good harvest.

Sakenwa is also called in Rai Bantawa language, Toshi in Thulung Rai language. Rai people worship Paruhang, Sumnima, nature and Nayima (forms of serpent). It was started by the goddess Sumnima, who firstly dances with happy and joy (Rai, B.S. 2063). Hatuwali argues that Sakela was introduced with creation of our universe and creatures. It was the one way of worship our creators Paruhang and Sumnima (Hatuwali, B.S. 2064). Bartman gives different aspects of origin of Sakela, he focuses on the political events in the reign of Buddhahang king of Dolakha. Her sister Soisoila made a beautiful crown, which was wear by king on the occasion worship of god Hanhuwang. Soisoila could not presence in the crown handed ceremony, crown was formed stone in the ground by the divine power. After that incident, Rai started to worship that stone and earth and celebrate Sakewa festival (Bartaman, B.S. 2053). 
Key informant Ram Rai asserts that Nachhung chooses the sacred place by his/her dream located area and the using Mundhumi power send to Washep (feather of bird) which is go in there, where Sakela Than is established. Rai people participate and confirms to establishment of Sakela Than collectively. The priest is called Sakela Dhami (Sakela Shaman) as like Durkhiem notion of collective consciousness.

Rai people worship three stones in Sakawa festival, which are symbolized earth, the universe and ancestors by Nakchung (Hatuwali, B.S. 2064). Key informant Sakela Nachhung Hasta Bahadur says about the role of Sakela Nachhung in Sakela festival.

Sakela Nachhung purifies the Sakela Than and also purifies their assistances such as Kanchhari (drum player), Tokaya (director), Mul Dhole (Main Drum Player), Silimompa (Dance master), Silimoma (Dance mistress). Waitung and Dhiatung all participate in Sakela puja in Sakela Than (residence of god). Sakela Nachhung worships the god and goddess by reciting Hwarisi (prose of Mundum). He/she worships by chanting the names of all creatures, universe, earth, sun, moon and sky. Then he/she offers local Janda, wine, rice and ginger, seedlings of paddy, seedling of maize and sacrifices cock, he-buffalo. $\mathrm{He}$ /she recites the Hwarisi for good framing and production and the forecast the future will be good or bad. He/she do Yari, by using Apa is a kind of forest ginger. He/she cuts Apa one by one and investigate the future of the community. All devotees give their worshipping goods to Sakela Nachhung for offering the god and goddess. He/she orders to start play Dhol and Jhymta (cymbal) and start to dance Sakela Sili. Dhol (Drum) are made by local tree but is selected by Nachhung spiritual power. After worship is completed, Nachhung leads the path with all assistances including carrying Seuli (branch of tree), where people perform Sakela Sili. Nachhung reaches the spot of dancing Sakela Sili, he/she purifies the spot and worships of the earth mother nature. He/she removes the evil spirits from the surrounding, where Sakela is performed. Nachhung gives permission to erect seuli Lingo then Muldhole plays the drum and Silmoppa and Silimomma start Sakela Sili. Sili is associated to the imitation of birds, animals and the expression of civilization process like hunting, gathering, farming. Nachhung/Nachnungma elaborates the all types of symbolic meaning of dances and its origination and importance in Rai community. Nachhung/Nachhungma recites the Mundum prose how the dances were originated and how their ancestors performed and transformed from generation to generation. All people can dance Sakela with happy and joy. All villagers like Chhetri, Tamang also participate in Sakela puja and and dancing Sakela Sili so we are binding in the name of Piple Sakela.

-Interview with Hasta Bahadur Rai, 2076/03/20 
The above statement shows that the Sakela festival is community festival, which is performed by whole Chamling Rai community and also other villager who are non Rai. Nachhung plays main role to protect and to bring prosperity in community and whole village. This festival makes social cohesion and village solidarity of Chamling Rai like Durkhiem notion.

\section{Nachhung's function in Hullung or Ubhauli Festival (upward worship of household deity)}

According to the key informants, a year divided into two seasons such as Ubhauli and Udhauli. Hullung is held in Ubhauli with in fifteen days, the day from Baishakhe Purnima (full moon) to Baishakhe Aushi (black moon). Hullung Puja is a kind of ritual of Ubhauli, which is concerned on household deities such as Chula Puja and Mochhama Puja. Nachhung plays great role to perform in Hullung. Rai social organization (Waitung) makes decision of the Hullung day. Pagari Dhami (appointed shaman) should perform this Puja. All members should participate in this Puja ceremony. It is started from the house of Waitung headman and then Nachhung and participants visit the every house of Waitung member. Mul Dhole (main drum player), Slimoppa, Silimomma are dancing in front of the house, Nachhung worships the Chula where reside the ancestors soul and god and goddess. Those soul which do not take ancestors, reside beyond Chula are also worship at eaves and courtyard. The Nachhung remedies all evils and ill from the house and wishes to enter the better health, wealth and crops.

\section{Nachhung's Function in Life Passage Ritual}

Ritual specialist Lachocha performs the death ritual to manage dead person's soul and transform the dead person's soul (cap) into an ancestor (khal). Unnatural deaths by drowning, burning, falling, and committing suicides become "bad dead" (hilsi, hillasi, etc.). Shamans trap bad spirits, exorcise witches, or kill the spirits of bad death (Schlemmer, 2019). Gaenszle (2004) Shaman and priest are ritual specialists whose functions are maintain a link to ancestors, remembering deeds, speaking to them in ritual invocation and interacting with them in ritual exchange.

According to Key informant, Nachhung performs Marimo Puja and Waiko Puja during the pregnancy period of women for better of child and mother, he/she protect from the bad evils and ancestors spirits. After child birth, Nachhung role is not necessary within six days. Nwaran (Naming ceremony) is performed after five or six days. In the past, Nachhung played role in Nwaran such as name was chosen, informed to new baby birth but nowadays, Nachhung do not need in Nwaran (naming ceremony). Similarly, Nachhung function is less in feeding ceremony and hair cutting ceremony. 
The Nachhung plays an important role in marriage ritual. He/she performs the Chula Puja (hearth with three erected stone) for happy marital life, prosperous life and long live marital relationship. Nachhung worships Chula at house of both bride and groom. He/she culturally take out bride from her father Chula and perform Bagdatta (promise words of parents to give his daughter to groom) in front of hearth. It means bride's houseside ritually transfer her daughter to groom. Similarly, Nachhung keep the name of bride in Chula of groom house. Ritually, bride lineage is transferred after end of this ritual. She is became ritually and culturally member of this house and whole clan organization.

Nakcho religious leader addresses the spirit of the dead and requests it to go to its final resting place to join the ancestors (Bista, 1996).

According to key informant, Chamling Rai buries dead body by Nachhung performing death ritual. Nachhung takes permission to dig out earth with recitation of earth Mundum. When pit is ready, then Nachhung cleans and purifies pit and manages to convince reside dead body here by reciting Mundum.

Khatwa Nachhung only performs to resting soul of natural death. After the lifting dead body in grave, Nachhung orders to all funeral participants give Matti (gives handful soil to dead body), After the three days mourning, Nachhung offers food, meat, local wine to departed soul. Chamling Rai believes that body is dead but soul is not dead. So, deceased person's soul is managed by Nachhung. Nachhung performs Yari (determine reside place of soul) ritual. Dead body soul is rested based on the death nature. The person who dies through natural and good ways, his/her soul rests on Chula and with ancestors. Departed soul rest with ancestor is known as Nikhali. The ritual is performed in the day by Pagari Dhami, whether he/she is Mapa or Khatwa. The person who dies through unnatural and bad ways, his/her soul does not rest on Chula and with ancestors. The ritual is performed in the day by Pagari Dhami, whether he/she is Mapa or Khatwa. Departed soul rests outside of the house or Chula is called Khali. This type of death ritual is held on throughout night, which is called Thulo Chinta (long healing ceremony) by only Mapa, Khatwa Nachhung do not this ceremony. Mapa directs the path of departed soul. Khali soul can divided into different types such as Siya Khali, Hachappa Khali, Hoduppa Khali, Tamrapo Hiropa, Mamo Hiropa, Chacha Khali. These Khali are resided appropriate place by Mapa Nachhung. Only Mapa Nachhung has to special function to eradicate or drive off evil spirits of unnatural death. On the occasion of Ubhauli and Udhauli these soul are offered ritual goods by Nachhung.

\section{Nachhung's Function in Healing Illness}

Good health of individual depends on interrelationship among individual body, one's familial, social, and cosmic relations. Shamans have power to control or combat spirits, ghosts and witches. They perform healing rituals to cure individual illness, familial 
wellbeing and prosperous. Shaman's function is to integrate the various communities into a broad network of shared commonalities and experience (Walter, 2003).

McDougal (1979) describes functions of the Nokachh (a part time priest) are performing Nagi Puja (water serpent), household rites, village rites and the Dhami (diviner and spirit medium) are curing sickness, warding off calamity and promoting family prosperity of Kulung Rai (McDougal, 1979).

The Jhankri himself that the magical powers, which represent the linkage between the shaman's alter state of consciousness and the therapeutic effects generated in patients by the shaman's ritual performances. Altered states of consciousness can influence healing by other means. Trance may promote health by psychophysiological or psychoneuroimmunological means (Sidky, 2009).

Needy house organized the night healing ceremony (Chinta Basne). It is basically organized to purpose one is treatment for ill persons and other is protect household from ancestors spirit, evil spirit and evaluation of evil planetary constellation. Like Gaenszle, shaman role is to remove severed evil planetary constellation (Grahadas Katnu). The shaman transfers the evil planetary constellation from household members to banana tree through the cotton thread (Gaenszle, 2004). It is also found that in the Chamling Rai. There is found a practice Grahsdas katnu with sacrifice hen, fish, ash gourd, crab, banana tree etc. Rai people believe that the Nachhung's supernatural power transfers person's evil planetary constellation to these animals and plants.

Chinta Basne purposes are different in the Chamling Rai community. House protection from night shaman ceremony is organized by house owner. Nachhung Hasta Bahadur Rai describes that the purpose of Ghar chinta are protection from the evil spirits, leave evil spirits from house, purify the bad place, haunted place and wrong place of house. The Nachhung forgives to every mistake by house owner and ask for fulfill household wishes as well as get protection and affluent forever. Other important function of Nachhung is to cure ill members of house.

Nachhung Akash Rai elaborates the Nachhung's function to heal ill member's house.

We Nachhungs are invited to heal ill member by ill member's house. At first, Dhami start to diagnosis what types of ill by touching pulse, feeling pulse, ill examination by counting rice kernels on brass plate with chanting Mandum. We get sign from the divination process. If it is minor illness, I will do simple healing ritual such as only Jharphuk (to cleanse and blow in healing spirits). If it is major illness, I will order to organize night healing ceremony. In accordance the cases, I will do Sir ubhyune (revive honor), I will do worship 
certain god, ancestor and deity, I will offer the name of cock and animal, I will ward off evil spirit in forest, at crossroad, in the bank of river and I will suck out evil spirits etc. In the case of pregnancy, I will perform Waiko Puja (water deity worship) and Marimo Puja. In the case of heart pain, I will away out Buwamori (cause of ill by clan members join illegal sexual relation within same blood group) and inform all Waitung member. In the case of lack of appetite, I will do Ulta Katne ritual. I also give the herbal medicine to patients. The diseases of abdomen pain may be cause of Nash or Bhed (intentionally caused by the evil eye such witches, sorceress), I will suck evil eyed things from abdomen by using Sikiya (instrument of Nachhung that is made by branch of bamboo) and paste of Kaulo (Persea odoratissima). I will also make Janter (folding written mantra, which is wore by patients) for long period sick persons.

-Interview with Nachhung Akash Rai 2076/03/26

\section{Conclusion}

Nachhung plays vital role of ritual socialization, which reinforces the common values in the Rai community. Nachhung also contributes to strengthen belief systems and taking cure from the disease and ill. Shaman is known as knowledge holder of holy Mundum of Chamling Rai. His/her main function is to transfer Mundum knowledge from generation to generation. He/she can explain universe, nature and god and goddess. Chamling Nachhung interprets and determines the social and cultural world of Chamling Rai. He/she gives high attention to communal prosperity, communal protection and creation by interlinking among spiritual, natural, psychological aspect of human. He/she can perform function as mediators between the profane world and sacred world. He/she is recognized as doctor of Chamling Rai, who performs healing process and make a healthy persons. He/she is herbalist, priest, ritualistic, spiritualistic, and naturalistic. He/she is mediums, witch doctors, spiritual healers or prophets but nowadays his/her functions are changing due to urbanization process, modernization and globalization process.

Nachhung origination process is not effective now. Nachhung is not available sufficiently in urban area. So Nachhung role is non-function. Those Chamling Rai who have followed other religion such Christian and Buddhist have dysfunction of Nachhung like with Merton's notion of manifest function and latent function, dysfunction and non-function.

\section{References}

Bista, D. B. (1996). People of Nepal (6th ed.). Kathmandu: Nepal.

Damain, W. (2003). Among spirits and deities: diverse shamanisms in the Nepal Himalayas, Cultural Survival Magazine, 27-2. 
Gaenslz, M. (2004). Rai shamanism. In M. N. Walter \& E. J. N. Fridman (Eds.), Shamanism: An encyclopedia of world beliefs, practices, and culture, Volume 1 (pp. 275- 277). California: ABC-CLIO.

Haralambos, M. \& R. M. Heald (2003). Sociology themes and perspective (20th ed.). New Delhi: Oxford University Press.

Hitchcock, J. T. (1976). Aspects of Bhujel shamanism. In J. T. Hitchcock and R. L. Jones (Eds.), Spirit possession in the Nepal Himalayas, (pp. 165-196). Warminster: Aris \& Phillips.

Jones, R. L. (1976). Limbu spirit possession and shamanism. In J.T. Hitchcock \& R.L. Jones (Eds.), Spirit possession in the Nepal Himalayas, (pp. 29-55). Warminster: Aris \& Phillips.

Lewis, L.M. (1984). What is shaman? In M. Hopal (Ed.), Shamanism in Eurasia, (Pp. 3-11). Gottingen: Edition Herodot.

McDougal, C. (1979). The Kulung Rai. Kathmandu: Ratna Pustak Bhandar.

Nicoletti, M. (2004). Shamanic solitudes: ecstasy, madness and spirit possession in the Nepal Himalaya. Kathmandu: Vajra Publication.

Reinhard, J. (1976). Shamanism among the Raji of southwest Nepal. In J.T. Hitchcock \& R.L. Jones (Eds.), Spirit possession in the Nepal Himalayas, (pp. 263-293). Warminster: Aris \& Phillips.

Sagant, P. (1976). Becoming a Limbu priest: ethnographic note. In J.T. Hitchcock \& R.L. Jones (Eds.), Spirit possession in the Nepal Himalayas, (pp. 55-99). Warminster: Aris \& Phillips.

Schlemmer, G. (2019). Following the ancestors managing the otherness. In M. Carrin (Ed.), Encyclopedia of the religions of indigenous people of South Asia. Leiden: Brill.

Sidky, H. (2009). A shaman's cure: The relationship between altered states of consciousness and shamanic healing, Anthropology of Consciousness 20(2):171-197

Townsend, J. B. (2001). Modern non-traditional and invented shamanism. In J. Pentikainen (Ed.), Shamanhood: symbolism and epic (pp. 257-264). Budapest: Akademiai Kiado.

Walter, M. N. (2004). Introduction. In M. N. Walter, \& E. J. N. Fridman (Eds.), Shamanism: an encyclopedia of world beliefs, practices, and culture, Volume 1 (pp. I- XXVIII). California: ABC-CLIO.

किरात राई चाम्लिङ खाम्बातिम (वि.सं. २०७१) मुन्दुम। काठमाडौं: किरात राई चाम्लिङ खाम्बातिम । मुकारुड, शुभ (वि.सं. २०६४) किरात र राई जाति । काठमाडौं: नेपाल फेडेरेसन अफ इन्डिजिनिअस ।

राई, कमलजंग (वि.सं. २०७३) साखेवा सिली। ललितपुर : आदिवासी जनजाति उत्थान राष्ट्रिय प्रतिष्ठान ।

राई, गडुलमान (वि.सं. २०६३) किरात संस्कार। ललितपुर : आदिवासी जनजाति उत्थान राष्ट्रिय प्रतिष्ठान ।

राई, राजुकुमार (वि. सं. २०७५) बान्तावा राई: समुदाय र संस्कृति। काठमाडौं: एकेडेमिक बुक सेन्टर ।

वर्तमान, नवराज (वि.सं. २०४३) साकेवाले भलो गरुन्, निप्सुङ; ४(२), पृ. ६।

हतुवाली, चन्द्रकुमार (वि. सं. २०६४) साकेन्वा: किराती राईहरुको महान् चाड। काठमाडौं: बान्ताव रिसर्च सेन्टर। 